\title{
Canine visceral leishmaniasis: perception, prevalence, and spatial distribution in municipality of Nossa Senhora do Livramento, Mato Grosso, Brazil
}

\author{
Leishmaniose visceral canina: percepção, prevalência e distribuição espacial \\ em Nossa Senhora do Livramento, Mato Grosso, Brazil \\ Matheus Roberto Carvalho' (D); Álvaro Felipe de Lima Ruy Dias ${ }^{1}$ (D); Arleana do Bom Parto Ferreira de Almeida² (D); \\ Mário Ribeiro Alves ${ }^{3}$ (D); Adilson Santos Paes $^{4}$ (i); Valéria Régia Franco Sousa²* (1)

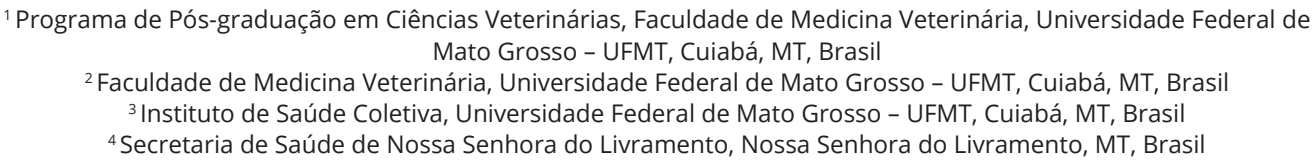

How to cite: Carvalho MR, Dias AFLR, Almeida ABPF, Alves MR, Paes AS, Sousa VRF. Canine visceral leishmaniasis: perception, prevalence, and spatial distribution in municipality of Nossa Senhora do Livramento, Mato Grosso, Brazil. Braz J Vet Parsito/ 2020; 29(2): e021019. https://doi.org/10.1590/S1984-29612020017

\begin{abstract}
The midwest region of Brazil has witnessed an increase in the number of cases of human (HVL) and canine visceral leishmaniasis (CVL). The aim of the present study was to evaluate the population's perception of these diseases, factors associated with CVL, its spatial distribution, and the prevalence of anti-Leishmania spp. in 385 dogs, determined using a commercially available immunochromatographic rapid test and confirmed using enzyme-linked immunosorbent assay (ELISA). Of the 385 samples, 54 were positive for CVL and confirmed by ELISA, corresponding to a prevalence of $14 \%$. Knowledge of signs of CVL by tutors ( $p=0.038$ ); previous occurrence of CVL in the vicinity $(p=0.022)$; symptomatic dog $(s)(p=0.014)$, splenomegaly $(p=0.055)$, and ear ulcer $(s)(p=0.059)$ were significantly associated with CVL. The results revealed a significant prevalence of CVL spatially distributed in rural and urban contexts. The association between environmentally related variables and perception and the occurrence of CVL underscores the importance of implementing control and prevention strategies primarily focused on environmental management and health education activities.
\end{abstract}

Keywords: Epidemiology, associated factors, Leishmania infantum.

\begin{abstract}
Resumo
No Brasil, a região Centro-Oeste tem apresentado aumento no número de casos de leishmaniose visceral humana (LVH) e canina (LVC). Com isso, o objetivo deste estudo foi avaliar a percepção da população em relação à doença, aos fatores associados a LVC, à distribuição espacial e à prevalência de anticorpos anti-Leishmania spp. em 385 cães, a partir do teste rápido imunocromatográfico e ensaio imunoenzimático (ELISA). Das 385 amostras, 54 foram reagentes para LVC e confirmadas no ELISA, correspondendo a prevalência de $14 \%$. O conhecimento dos sinais da LVC pelos tutores $(p=0,038)$, a ocorrência prévia da LVC na vizinhança $(p=0,022)$, o cão sintomático ( $p$ $=0,014)$, esplenomegalia $(p=0,055)$ e apresentar úlcera em ponta de orelha $(p=0,059)$ foram significativamente associados à LVC. Os resultados demonstram expressiva prevalência de LVC, distribuídas espacialmente no contexto rural e urbano, e a associação de variáveis relacionadas ao ambiente e à percepção com a ocorrência da LVC ressaltam a importância da implementação de estratégias de controle e prevenção, focadas principalmente no manejo ambiental e em atividades de educação em saúde.
\end{abstract}

Palavras-chave: Epidemiologia, fatores associados, Leishmania infantum. 


\section{Introduction}

Visceral leishmaniasis (VL) is a potentially fatal anthropozoonosis, with an estimated incidence of 50,000 to 90,000 new human cases worldwide each year (WHO, 2019). The canine form of VL (CVL) is recognized by the World Organisation for Animal Health (OIE) as an important disease due to its clinical characteristics, transmissibility and zoonotic potential, and the number of regions becoming Leishmania endemic has grown significantly in recent years (OIE, 2020).

In the Americas, Brazil accounts for approximately $96 \%$ of cases of human VL (HVL), which continues to experience geographic expansion, mainly in the Northeast, Southeast, and Midwest (OPAS, 2018a) regions. Moreoever, most cases of CVL are also reported in Brazil (WHO, 2019), with Leishmania infantum (Kinetoplastida, Trypanosomatidae) being the etiological agent (Ready, 2014), which is transmitted to vertebrate hosts mainly by two species of Phlebotominae, Lutzomyia longipalpis and Lutzomyia cruzi (Missawa \& Lima, 2006).

Leishmania infantum transmission control measures recommended by the Brazilian Ministry of Health are focused on the diagnosis and treatment of human cases, reduction of the phlebotomine population, and measures to combat the reservoir, including diagnosis and euthanasia of seroreactive dogs (Brasil, 2014). According to Alemu et al. (2013), the effectiveness of VL control and prevention programmes depend on active participation of the population because there is a relationship between environmental variables and vector density. Therefore, it is important to understand the population's level of information about this disease, as well as its attitudes and practices regarding prevention. In addition, the use of spatial analysis tools makes it possible to understand the disease expansion process, including spatial patterns of distribution and identification of risk areas (Silva et al., 2017).

Widely accepted in the scientific community, the occurrence of HVL is associated with poor socioeconomic, environmental, and housing conditions (Belo et al., 2013; Bruhn et al., 2018; Diniz et al., 2018). In this sense, studies assessing the prevalence of CVL seek to highlight factors associated with canine infection, especially those intrinsic to dogs, as well as environmental aspects (Coura-Vital et al., 2011; Dias et al., 2017; Leal et al., 2018) and the association between the population's level of knowledge and the occurrence of CVL (Margonari et al., 2012; Menezes et al., 2016).

Lutzomyia longipalpis vector has been reported in Mato Grosso, in the city of Nossa Senhora do Livramento, Brazil (Missawa \& Lima, 2006) and, in the triennium of 2015, 2016 and 2017, the mean incidence of HVL was 8.26\% (OPAS, 2018b). The municipality has a medium index of human development (IBGE, 2018), and human occupation is associated with agricultural activities and mineral extraction. Thus, the present study aimed to investigate the population's perception of $\mathrm{VL}$, the prevalence of anti-Leishmania species (spp.) antibodies in dogs, associated factors, and the spatial distribution of canine disease in Nossa Senhora do Livramento.

\section{Material and Methods}

\section{Study area}

The present cross-sectional study was conducted between July and August 2018 in the municipality of Nossa

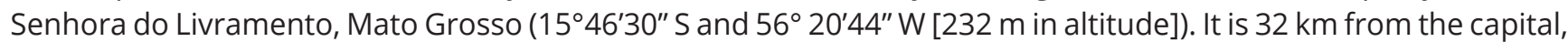
Cuiabá, and belongs to the physiographic zone of the Pantanal, located in the central-south mesoregion of Mato Grosso and Cuiabá microregion, with a warm and humid tropical climate, and an average temperature of $24^{\circ} \mathrm{C}$ (IBGE, 2018).

\section{Sampling and description of animals}

Considered the equation $n=Z_{\frac{\alpha}{2}}^{2} \frac{p(1-p)}{d^{2}}\left(z_{\frac{\alpha}{2}}^{2}\right.$ is a tabulated value of the normal distribution, $p$ is the proportion of successes or prevalence and $d^{2}$ is the estimate margin of error), the calculated sample size was 385 dogs, which considered the ratio of dogs to humans in the area of 7:1 and a population estimated in 2017 to be 12.484 inhabitants in a territorial extension of $4.934 .713 \mathrm{~km}^{2}$ (IBGE, 2018), with a confidence level of 95\%, acceptable error of 5\%, and prevalence of $50 \%$ (Brasil, 2014), using the software Epilnfo (7.1.4). Domiciled dogs of both sexes, of different breeds, and $\geq 6$ months of age were included (CDC, 2014). 


\section{Clinical evaluation and sample collection}

Dogs were examined and classified according to the method described by Solano-Gallego et al. (2009) in symptomatic and asymptomatic animals. Initially, local asepsis of the skin was performed with $70 \%$ ethyl alcohol and, with sterile syringe, approximately $10 \mathrm{~mL}$ of blood was collected by puncture of the external or cephalic jugular vein. Serum was separated by centrifugation and stored at $-20^{\circ} \mathrm{C}$ until processing.

The present study was approved by the Animal Ethics Committee of the Federal University of Mato Grosso (CEUA-UFMT; Number 23108.942583/2018-82), and all procedures were performed only after written consent was provided by the tutors of the animals.

\section{Serological diagnosis}

Serological diagnosis was performed using a commercially available immunochromatographic test (Dual Path Platform [DPP], ChemBio Diagnostic Systems Inc., Medford, NJ, USA) that uses the recombinant protein k28 (fragments k26, k39 and k9) as antigen, isolated from L. (L.) donovani, for screening. The enzyme-linked immunosorbent assay (ELISA), wich uses the soluble and lysate antigen of Leishmania major-like, as a confirmatory test (Brasil, 2011), according to manufacturer's instuctions (Bio-Manguinhos/Fiocruz, Brazil).

\section{Epidemiological and perception analysis}

Information regarding the living environment (proximity to areas of vegetation, rivers or bays, presence of other domestic animals, presence of trees, vegetable gardens or livestock in the backyard of houses, and whether there was public garbage collection), as well as dog population characteristics (breed, sex, age, house function, and presence of clinical signs) were obtained using an epidemiological questionnaire. Perception was assessed by interviews querying guardians' knowledge of the disease (etiological agent, vector, and hosts), and prevention and control measures.

\section{Spatial analysis}

Geographical locations were identified using global positioning equipment (Monterra, Garmin, Olathe, Kansas, USA), with each household visited represented by a mark. Thus, dogs residing in the same household were registered at the same geographical point.

For spatial visualisation of the point pattern, the dogs' location was plotted using the geographical coordinates to construct a point map. The kernel intensity estimate was then calculated to evaluate the density of the points. All of these procedures were performed in the ArcGIS 10.3 software.

\section{Statistical analysis}

Prevalence values and corresponding 95\% confidence intervals were calculated. The association between the prevalence of anti-Leishmania spp. antibodies in dogs and independent variables was performed by two-step logistic regression (i.e., univariate and multivariate analysis). Variables with $p \leq 0.20$ in the chi-squared test were selected for multivariate analysis, and differences with $p \leq 0.05$ were considered to be statistically significant.

The chi-squared test was used to assess perception, as a means of comparing the statistical differences between the responses obtained for each variable and assessing the association between respondents' responses and CVL serology. All analyses were performed using the R statistical package version 3.4.4 (R Core Team, 2018).

\section{Ethics statement}

In this study, all procedures using animals complied with the Ethical Principles in Animal Research adopted by the College of Animal Experimentation (COBEA) and were approved (protocol number 23108.942583/2018-82) by the Animal Research Ethics Committee of the Federal University of Mato Grosso, Brazil.

\section{Results}

Of the 385 dogs analysed, 54 were TR-DPP reagent-positive in the screening test and confirmed by ELISA, corresponding to a prevalence of $14 \%$ for CVL in the municipality of Nossa Senhora do Livramento. Considering reactive dogs, no significant differences were observed according to sex and breed (only two reactive purebred dogs, Boxer and American Pitbull were detected) (Table 1). 
Table 1. Univariate and multivariate analyses between dog characteristics and the prevalence of canine visceral leishmaniasis in Nossa Senhora do Livramento, Mato Grosso, Brazil.

\begin{tabular}{|c|c|c|c|c|c|}
\hline \multirow{2}{*}{ Variables } & $\begin{array}{l}\text { Seroreactive } \\
\text { dogs/Sampled }\end{array}$ & Prevalence & \multirow{2}{*}{ OR (CI 95\%) } & \multirow{2}{*}{$\begin{array}{c}\begin{array}{c}\text { Univariate } \\
\text { analysis }\end{array} \\
\text { p-value* }\end{array}$} & \multirow{2}{*}{$\begin{array}{c}\begin{array}{c}\text { Multivariate } \\
\text { analysis }\end{array} \\
p \text {-value** }\end{array}$} \\
\hline & $(54 / 385)$ & $(\%)$ & & & \\
\hline \multicolumn{6}{|l|}{ Gender } \\
\hline Male & $33 / 223$ & 14.7 & & & \\
\hline Female & $21 / 162$ & 12.9 & $1.16(0.64-2.10)$ & 0.608 & \\
\hline \multicolumn{6}{|l|}{ Breed } \\
\hline Pure & $52 / 375$ & 13.8 & & & \\
\hline Mixed & $2 / 10$ & 20 & $0.64(0.13-3.11)$ & 0.928 & \\
\hline \multicolumn{6}{|l|}{ Age groups } \\
\hline$\geq 0.5-y 1$ & $7 / 76$ & 9.2 & - & - & \\
\hline$>1-\leq 3 y$ & $21 / 136$ & 15.4 & $0.55(0.22-1.37)$ & 0.198 & \\
\hline$>3-\leq 7 y$ & $8 / 78$ & 10.2 & $0.88(0.30-2.58)$ & 0.826 & \\
\hline$>7 y$ & $15 / 68$ & 22 & $0.35(0.13-0.94)$ & 0.032 & 0.627 \\
\hline Undefined age & $3 / 27$ & 11.1 & $0.81(0.19-3.39)$ & 0.774 & \\
\hline \multicolumn{6}{|l|}{ Symptomatology } \\
\hline Symptomatic & $49 / 295$ & 16.6 & $3.38(1.30-8.77)$ & 0.008 & 0.014 \\
\hline Asymptomatic & $5 / 90$ & 50 & & & \\
\hline
\end{tabular}

OR: Odds Rattio (confidence interval); *Chi-square with Yate's correction and Fisher exact test; **Logistic Regression Model.

Regarding age distribution, the population consisted mainly of dogs between 1 and 3 years of age, followed by those 3 to 7 years of age, thus characterizing a young adult population. When considering the home function performed by the reactant dogs, most were considered guard and companion dogs (48.1\%), which was not statistically different from animals that were guard only (20.3\%) or companion only (31.4\%).

Regarding the clinical evaluation of reactant dogs, a large proportion consisted of symptomatic animals and an asymptomatic minority, with a statistical difference between the groups (Table 1). Among dogs with CVL, the most frequent clinical signs included localized lymphadenopathy (38.8\%), splenomegaly (35.1\%), skin lesions (35.1\%), and generalized lymphadenopathy (25.9\%). There were significant differences in the univariate analysis for skin lesions ( $p=0.001)$ and, in multivariate analysis, ear ulcer $(p=0.059)$ and splenomegaly $(p=0.055)$. Regarding the body score of reactive dogs, $57.4 \%$ were classified as normal, $38.8 \%$ as thin, and $3.7 \%$ as very thin.

When considering the location of residence, a statistical difference was observed in the univariate analysis for dogs that lived in the urban area compared with the rural area (Table 2). These residences were mostly located near forests, followed by rivers/streams, with higher risks for the occurrence of the disease in both contexts (Table 2), and a smaller portion was located in urban areas without proximity to forests and/or rivers/streams. Most of the backyards of these residences consisted of land and cemented areas (61.1\%), land only (37\%), and lawn only (1.8\%).

There were plantations in $70.3 \%$ of these backyards and, in $29.6 \%$, no practices of vegetable cultivation were observed. Other environmental and demographic factors associated with canine positivity in the univariate analysis included the following: presence of chicken coop(s); small rodents/marsupials; practice of dedetization in the house; and lack of public garbage collection. On multivariate analysis, knowledge of the occurrence of CVL in the vicinity was associated with canine positivity (Table 2). 
Table 2. Univariate and multivariate analyzes to assess the association between environmental characteristics and the occurrence of canine visceral leishmaniasis in Nossa Senhora do Livramento, Mato Grosso, Brazil.

\begin{tabular}{|c|c|c|c|c|c|}
\hline \multirow[t]{2}{*}{ Variables } & $\begin{array}{l}\text { Seroreactive } \\
\text { dogs/Sampled }\end{array}$ & Prevalence & \multirow{2}{*}{ OR (CI 95\%) } & \multirow{2}{*}{$\begin{array}{c}\begin{array}{c}\text { Univariate } \\
\text { analysis }\end{array} \\
\text { p-value* }\end{array}$} & \multirow{2}{*}{$\begin{array}{c}\begin{array}{c}\text { Multivariate } \\
\text { analysis }\end{array} \\
p \text {-value** }\end{array}$} \\
\hline & $(54 / 385)$ & $(\%)$ & & & \\
\hline \multicolumn{6}{|l|}{ Residence location } \\
\hline Urban area & $14 / 159$ & 8.8 & $0.44(0.23-0.85)$ & 0.013 & 0.200 \\
\hline Countryside area & $40 / 226$ & 17.7 & & & \\
\hline \multicolumn{6}{|l|}{ Proximity of residence } \\
\hline Forest & $41 / 273$ & 15 & $1.34(0.69-2.62)$ & 0.475 & \\
\hline Forest and river & $9 / 38$ & 23.6 & $1.88(0.80-4.38)$ & 0.216 & \\
\hline None of the options & $4 / 74$ & 5.4 & -- & & \\
\hline \multicolumn{6}{|l|}{ CVL in the vicinity } \\
\hline Yes & $7 / 19$ & 36.8 & $3.95(1.48-10.56)$ & 0.003 & 0.022 \\
\hline No & $47 / 366$ & 12.8 & & & \\
\hline \multicolumn{6}{|l|}{ Rodents and marsupials } \\
\hline Yes & $44 / 257$ & 17.1 & $2.40(1.20-5.25)$ & 0.020 & 0.138 \\
\hline No & $10 / 128$ & 8.3 & & & \\
\hline \multicolumn{6}{|l|}{ Hen house } \\
\hline Yes & $45 / 274$ & 16.4 & $2.22(1.04-4.72)$ & 0.049 & 0.327 \\
\hline No & $9 / 111$ & 8.1 & & & \\
\hline \multicolumn{6}{|l|}{ Garbage collection } \\
\hline Yes & $20 / 207$ & 9.6 & $0.45(0.25-0.82)$ & 0.012 & 0.079 \\
\hline No & $34 / 178$ & 19.1 & & & \\
\hline \multicolumn{6}{|l|}{ Trees in the yard } \\
\hline Yes & $38 / 249$ & 15.2 & $1.35(0.72-2.52)$ & 0.344 & \\
\hline No & $16 / 136$ & 11.7 & & & \\
\hline \multicolumn{6}{|l|}{ Inseticide use } \\
\hline Yes & $6 / 13$ & 46.15 & $5.78(1.86-17.94)$ & 0.004 & 0.089 \\
\hline No & $48 / 372$ & 12.90 & & & \\
\hline
\end{tabular}

CVL: Canine visceral leishmaniasis; OR: Odds Ratio (confidence interval); *Chi-square with Yate's correction and Fisher's Exact test; ** Logistic Regression Model.

\section{Owners' perception of $\mathrm{VL}$}

A total of 167 interviews were conducted with the guardians of the 385 dogs evaluated in the study and, of these, $68.9 \%$ of individuals had heard about $\mathrm{VL}$, and $31 \%$ were unaware of the disease. Of those who had heard about VL, 68.4\% knew that the disease can also affect humans, and only $19.1 \%$ reported knowing at least one clinical sign of VL in humans, and the most cited clinical sign was injuries (12.3\%).

Most respondents were unaware of routes of transmission (Table 3), and 15.3\% reported that mosquitoes were the disease vectors, but could not specify which species, 9.1\% reported they were by direct contact with a positive dog, 3\% answered "straw mosquito", $2 \%$ reported "dengue mosquito", 2\% reported tick, and 2\% associated transmission with a bite from a sick dog. 
Table 3. Perception of the interviewed population regarding canine visceral leishmaniasis and univariate analysis for evaluation between responses and disease occurrence in Nossa Senhora do Livramento, Mato Grosso, Brazil.

\begin{tabular}{|c|c|c|c|c|c|c|}
\hline \multirow{2}{*}{ Variables } & \multicolumn{2}{|c|}{ Number of answers } & \multicolumn{2}{|c|}{ Seroreactive dogs } & \multirow{2}{*}{ OR (CI 95\%) } & \multirow{2}{*}{$\begin{array}{c}\begin{array}{c}\text { Univariate } \\
\text { analysis }\end{array} \\
p \text {-value* }\end{array}$} \\
\hline & $\mathbf{N}$ & $\%$ & $\mathbf{N}$ & $\%$ & & \\
\hline \multicolumn{7}{|c|}{ Have heard about VL } \\
\hline Yes & 115 & 68.8 & 28 & 24.3 & \multirow[t]{2}{*}{$0.32(0.16-0.64)$} & \multirow[t]{2}{*}{0.001} \\
\hline No & 52 & 31.1 & 26 & 50 & & \\
\hline \multicolumn{7}{|l|}{ Know transmission } \\
\hline Yes & 55 & 32.9 & 12 & 21.1 & \multirow{2}{*}{$0.46(0.22-0.98)$} & \multirow[b]{2}{*}{0.062} \\
\hline No & 112 & 67 & 42 & 37.5 & & \\
\hline \multicolumn{7}{|l|}{ Know CVL signals } \\
\hline Yes & 57 & 34.1 & 12 & 21 & \multirow{2}{*}{$0.43(0.20-0.90)$} & \multirow{2}{*}{0.038} \\
\hline No & 110 & 65.8 & 42 & 38.1 & & \\
\hline \multicolumn{7}{|c|}{ Know CVL treatement } \\
\hline Yes & 36 & 21.5 & 8 & 22.2 & \multirow{2}{*}{$0.52(0.22-1.25)$} & \multirow{2}{*}{0.206} \\
\hline No & 131 & 78.4 & 46 & 35.1 & & \\
\hline \multicolumn{7}{|c|}{ There is CVL vaccine } \\
\hline Yes & 23 & 13.7 & 2 & 8.6 & \multirow{2}{*}{$0.16(0.37-0.74)$} & \multirow{2}{*}{0.070} \\
\hline No & 144 & 86.2 & 52 & 36.1 & & \\
\hline \multicolumn{7}{|c|}{ Know how to prevent } \\
\hline Yes & 19 & 11.3 & 3 & 15.7 & \multirow[t]{2}{*}{$0.35(0.99-1.28)$} & \multirow[t]{2}{*}{0.126} \\
\hline No & 148 & 88.6 & 51 & 34.4 & & \\
\hline
\end{tabular}

VL: Visceral leishmaniasis; CVL: Canine visceral leishmaniasis; OR: Odds Ratio (confidence interval); *Chi-square with Yate's correction and Fisher's Exact test.

The variable "knows the clinical signs of CVL" was related to the occurrence of the disease (Table 3), being the most cited by the interviewees: large nails, wounds, hair loss, itching, and weight loss. Approximately $86.5 \%$ of respondents answered that there is no cure for the canine form of the disease (i.e., CVL) and $24.7 \%$ reported that there was treatment; however, $75.2 \%$ of these did not know about treatment.

When asked how to prevent CVL, most respondents were completely unaware of the existence of preventive measures (Table 3). Maintenance of a clean yard was mentioned by $4.2 \%$ of tutors, euthanasia of reactive dogs by $3 \%$, avoidance of contact with the vector by $2.4 \%$, vaccination by $2.4 \%$, and $1.8 \%$ responded with avoiding contact with a positive dog.

\section{Spatial visualisation}

Based on the point map, cases of CVL were scattered throughout practically all sampled areas of the municipality. However, through the kernel density estimator (Figure 1), it was possible to visualize a greater intensity of CVL cases recorded in the northeast region of Nossa Senhora do Livramento.

\section{Discussion}

Results of the present study revealed a CVL prevalence of $14 \%$ in the municipality of Nossa Senhora do Livramento, Brazil. In a state context, lower prevalence rates have been observed in other cities of Mato Grosso - 7.8\% in Poxoréo (Azevedo et al., 2008) and 4.2\% in Barão de Melgaço (Dias et al., 2017) - and the highest prevalences were reported by Duarte (2010): 48.4\% in Rondonópolis, and 22.1\% in the state capital Cuiabá (Almeida et al., 2012). 

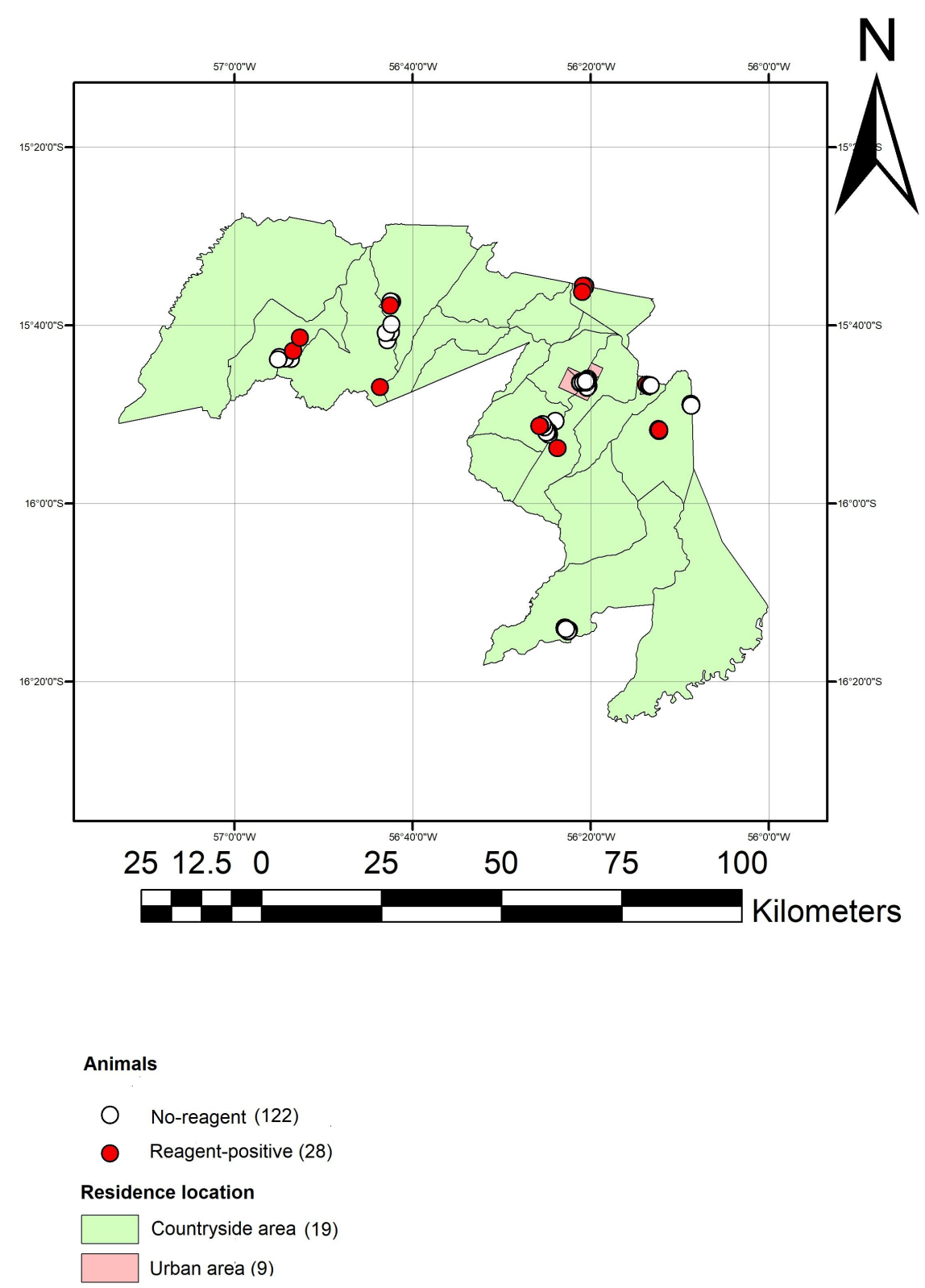

Figure 1. Spatial distribution of dogs sampled and Visceral Leishmaniasis reagents in the municipality of Nossa Senhora do Livramento - MT.

Different prevalences were also observed in other regions of Brazil (Barbosa et al., 2010; D'Andrea et al., 2015), and may be due to different diagnostic methods used, with variations in specificity and sensitivity, as well as size and selection of the sampled population, the type of study, and local environmental characteristics (Solano-Gallego et al., 2009).

Regarding age, although univariate analysis was significant for dogs $>7$ years of age, age was not a factor associated with canine infection in the multivariate analysis. Results regarding the age variable have been inconsitent among studies. For example, there are many reports of a higher prevalence of the disease in young dogs (Dantas-Torres et al., 2006; Figueiredo et al., 2014), which may be associated with immunological immaturity. In other studies, higher prevalences were observed in adult to elderly animals (Coura-Vital et al., 2011), which would be associated with the longer incubation period of the parasite, as well as longer exposure time to the vector (Gállego, 2004). There is also the possibility of a bimodal distribution of seroprevalence in relation to age, with a peak being observed among young animals, and a second, more significant peak among older animals (Gálvez et al., 2010).

In the present study, symptomatic dogs, more specifically, those with at least one clinical sign associated with $\mathrm{CVL}$, were three times more likely to be seroreactive compared with asymptomatic dogs, which is consitent with 
the observations of other studies (Figueiredo et al., 2014; Dias et al., 2017). According to Coura-Vital et al. (2013), the association between clinical signs and positivity is due to seroconversion, mainly because symptomatic sick dogs exhibit higher levels of anti-Leishmania spp. antibodies.

Splenomegaly and skin lesions, especially ear ulcers, were clinical signs that were positively related to canine infection, corroborating clinical findings from other epidemiological studies (Rondon et al., 2008; Queiroz et al., 2009; Islam et al., 2017). However, an important factor in maintaining the epidemiological cycle of VL is asymptomatic reagent-positive dogs, which has been reported in different studies (Dantas-Torres et al., 2006; Coura-Vital et al., 2011) because they remain in the environment with the potential to infect the vectors (Molina et al., 1994) and maintain the transmission cycle.

Considering the results of univariate analysis in the municipality studied, the prevalence of seroreactive dogs was higher in the rural zone and differed from the urban zone. This high prevalence in the rural area was associated with the presence of chicken coops and rodents/marsupials in the households visited.

According to Ávila et al. (2018), the environmental context facilitates maintenance and dispersion of the vector. Thus, the observation of high prevalence of CVL in dogs living in rural environments serves as a warning indicator of higher risk for infection in the rural population, because in this municipality (IBGE, 2010), as in the study by Dias et al. (2017), the largest proportion of the human population lived in rural areas.

Continuing with environmental variables, the univariate analysis revealed that the lack of public garbage collection was a risk factor for CVL. Such a result was also reported to contribute to a higher risk for canine and human disease in a previous study (Dias et al., 2018; Lima et al., 2018). According to Oliveira \& Araújo (2003), residues in the peridomicile can serve as a shelter and breeding ground for vectors, which may explain why previous occurrence of CVL in the neighborhood in our study was a risk factor for infection. Therefore, households with previous occurrence of CVL represent an obvious risk for infection of other dogs in the house, aside from offering favorable environmental conditions for the vector(s), thus favoring new cases of the disease (Dereure et al., 2003).

To reduce the risk for CVL in Brazil, the leishmaniasis control and prevention programme recommends actions on different fronts and encourages action from the population in disease control measures. In this study, when we assessed the perception of the guardians of dogs sampled, $86.58 \%$ were unaware of the existence of preventive measures for the disease. Margonari et al. (2012) also reported superficial knowledge and low participation of the population in the control and prevention of VL. Menezes et al. (2016) commented that this fragmented perception of VL does not permit a deep understanding or recognition of all components of the epidemiological chain of the disease.

In this sense, the relationship between seroreactive dogs and the variables, "have heard about VL" and "know the symptoms of CVL", can be understood as measures of previous exposure to the disease, explaining, for example, the risk for occurrence of CVL being almost six times higher in homes that have already been sprayed with insecticides. Similar results were reported by Coura-Vital et al. (2011), who observed that dogs whose owners knew the vector was associated with a higher risk for infection compared with dog owners who were unaware of this information.

Regarding spatial assessment, several studies focused on the geographical distribution of HVL (Silva et al., 2017; Galgamuwa et al., 2018) and CVL (Ursine et al., 2016; Lana et al., 2018). To our knowledge, however, the present study was the first to use a spatial approach to canine disease in Nossa Senhora do Livramento, although the municipality has annually reported cases of HVL since 2015 (Mato Grosso, 2019).

Despite the point map demonstrating a wide distribution of reactant dogs in the assessed areas, the fact that several dogs resided at the same coordinates made it difficult to identify patterns of infection. However, with the intensity map (Figure 2), it was possible to see that the urban area (of a smaller territorial extension), represented by the black color, indicated a higher intensity of reactive dogs. More specifically, despite a lower prevalence of CVL in relation to rural areas, the urban population is also at risk for infection, which further supports the process of urbanisation of the disease described in several previous studies (Duarte, 2010; Gálvez et al., 2010; Pimentel et al., 2015).

Considering the data obtained in this study, a significant prevalence of CVL was observed in Nossa Senhora do Livramento, which should raise awareness to the risk for new human cases, given that canine disease precedes human disease. Factors inherent to dogs, the environment, and population perception were associated with the occurrence of $\mathrm{CVL}$, observed spatially in both rural and urban contexts.

Thus, these data reaffirm the classification of VL as a neglected disease, where endemics are observed in low-income populations in poor or developing countries with poor infrastructure and emphasizes the importance of epidemiological surveillance and the need to implement control and prevention strategies for CVL focused mainly on environmental management and health education activities. 


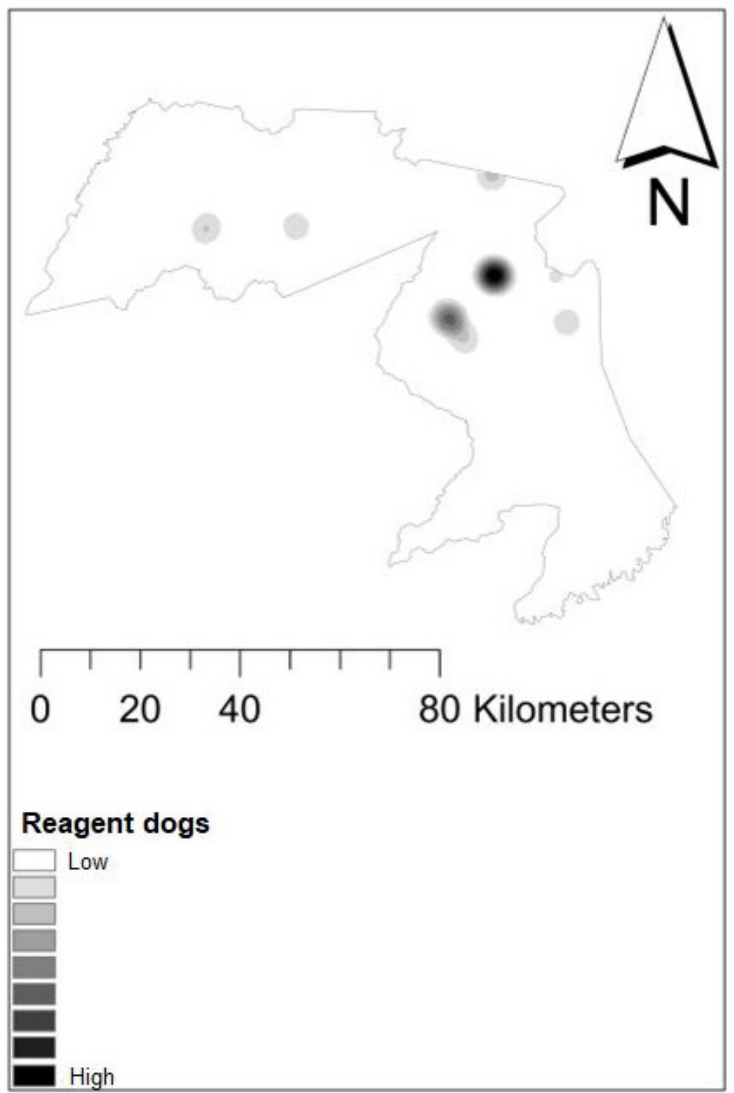

Figure 2. Kernel map, identifying low to high density regions of Canine Visceral Leishmaniasis in Nossa Senhora do Livramento - MT.

\section{Acknowledgements}

We thank the Ministry of Health for providing the Dual Path Platform (DPP ${ }^{\circledR}$ ) and enzyme-linked immunosorbent assay (ELISA) tests used in this research. We are also grateful to the Secretary of Health of the State of Mato Grosso and the Secretariat of Health of the municipality of Nossa Senhora do Livramento (Locimar Bispo da Silva). To Coordenação de Aperfeiçoamento de Pessoal de Nível Superior for grating the scholarship.

\section{References}

Alemu A, Alemu A, Esmael N, Dessie Y, Hamdu K, Mathewos B, et al. Knowledge, attitude and practices related to visceral leishmaniasis among residents in Addis Zemen town, South Gondar, Northwest Ethiopia. BMC Public Health 2013; $13(1)$ : 382. http://dx.doi.org/10.1186/1471-2458-13-382. PMid:23617595.

Almeida ABPF, Sousa VRF, Cruz FACS, Dahroug MAA, Figueiredo FB, Madeira MF. Canine visceral leishmaniasis: seroprevalence and risk factors in Cuiabá, Mato Grosso, Brazil. Rev Bras Parasitol Vet 2012; 21(4): 359-365. http://dx.doi.org/10.1590/S198429612012005000005 . PMid:23184322.

Ávila MM, Brilhante AF, Souza CF, Bevilacqua PD, Galati EAB, Brazil RP. Ecology, feeding and natural infection by Leishmania spp. of phlebotomine sand flies in an area of high incidence of American tegumentary leishmaniasis in the municipality of Rio Branco, Acre, Brazil. Parasit Vectors 2018; 11(1): 64. http://dx.doi.org/10.1186/s13071-018-2641-y. PMid:29373995.

Azevedo MÁA, Dias AKK, Paula HB, Perri SHV, Nunes CM. Avaliação da leishmaniose visceral canina em Poxoréo, Estado do Mato Grosso, Brazil. Rev Bras Parasitol Vet 2008; 17(3): 123-127. http://dx.doi.org/10.1590/S1984-29612008000300001. PMid:19245756.

Barbosa DS, Rocha AL, Santana AA, Souza CSF, Dias RA, Costa-Júnior LM, et al. Soroprevalência e variáveis epidemiológicas associadas à leishmaniose visceral canina em área endêmica no município de São Luís, Maranhão, Brasil. Cienc Anim Bras 2010; 11(3): 653-659. http://dx.doi.org/10.5216/cab.v11i3.5933.

Belo VS, Werneck GL, Barbosa DS, Simões TC, Nascimento BW, da Silva ES, et al. Factors associated with visceral leishmaniasis in the Americas: a systematic review and meta-analysis. PLoS Neg/ Trop Dis 2013; 7(4): e2182. http://dx.doi.org/10.1371/journal. pntd.0002182. PMid:23638203. 
Brasil. Ministério da Saúde. Nota técnica conjunta n 01/2011- CGDT/DEVIT/SUS/MS: esclarecimento sobre a substituição do protocolo diagnóstico da leishmaniose visceral canina (LVC). Brasília: Ministério da Saúde; 2011.

Brasil. Ministério da Saúde. Manual de vigilância e controle da Leishmaniose Visceral. Brasília: Ministério da Saúde; 2014.122 p.

Bruhn FRP, Morais MHF, Bruhn NCP, Cardoso DL, Ferreira F, Rocha CMBM. Human visceral leishmaniasis: factors associated with deaths in Belo Horizonte, Minas Gerais state, Brazil from 2006 to 2013. Epidemiol Infect 2018; 146(5): 565-570. http://dx.doi. org/10.1017/S0950268818000109. PMid:29463341.

Centers for Disease Control and Prevetion - CDC. EPI INFO' 7. Version 7.1.4 [online]. Atlanta: CDC; 2014 [cited 2018 June 14]. Available from: http://www.cdc.gov/epiinfo

Coura-Vital W, Marques MJ, Veloso VM, Roatt BM, Aguiar-Soares RDO, Reis LES, et al. Prevalence and factors associated with Leishmania infantum infection of dogs from an urban area of brazil as identified by molecular methods. PLoS Negl Trop Dis 2011; 5(8): e1291. http://dx.doi.org/10.1371/journal.pntd.0001291. PMid:21858243.

Coura-Vital W, Reis AB, Fausto MA, Leal GGA, Marques MJ, Veloso VM, et al. Risk factors for seroconversion by Leishmania infantum in a cohort of dogs from an endemic area of Brazil. PLoS One 2013; 8(8): e71833. http://dx.doi.org/10.1371/journal. pone.0071833. PMid:23990996.

D'Andrea LAZ, da Silva Fonseca E, Prestes-Carneiro LE, Guimarães RB, Yamashita RC, Soares CN, et al. The shadows of a ghost: a survey of canine leishmaniasis in Presidente Prudente and its spatial dispersion in the western region of São Paulo state, an emerging focus of visceral leishmaniasis in Brazil. BMC Vet Res 2015; 11(1): 273. http://dx.doi.org/10.1186/s12917-015-0583-6. PMid:26503368.

Dantas-Torres F, Brito MEF, Brandão-Filho SP. Seroepidemiological survey on canine leishmaniasis among dogs from an urban area of Brazil. Vet Parasitol 2006; 140(1-2): 54-60. http://dx.doi.org/10.1016/j.vetpar.2006.03.008. PMid:16621286.

Dereure J, El-Safi SH, Bucheton B, Boni H, Kheir MM, Davoust B, et al. Visceral leishmaniasis in eastem Sudan: parasite identification in humans and dogs; host-parasite relationships. Microbes Infect 2003; 5(12): 1103-1108. http://dx.doi.org/10.1016/j. micinf.2003.07.003. PMid:14554251.

Dias AFLR, Almeida ABPF, Cruz FACS, Silva RR, Rodrigues JY, Otsubo AAF, et al. Seroprevalence and spatial analysis of canine visceral Leishmaniasis in the Pantanal Region, Mato Grosso State, Brazil. J Zoonotic Dis Public Health 2017; 1: 3.

Dias RCF, Thomaz-Soccol V, Pasquali AKS, Alban SM, Fendrich RC, Pozzolo EM, et al. Variables associated with the prevalence of anti-Leishmania spp. antibodies in dogs on the tri-border of Foz do Iguaçu, Paraná, Brazil. Rev Bras Parasitol Vet 2018; 27(3): 338-347. http://dx.doi.org/10.1590/s1984-296120180055. PMid:30184001.

Diniz LFB, Souza CDF, Carmo RF. Epidemiology of human visceral leishmaniasis in the urban centers of the lower-middle São Francisco Valley, Brazilian semiarid region. Rev Soc Bras Med Trop 2018; 51(4): 461-466. http://dx.doi.org/10.1590/0037-86820074-2018. PMid:30133628.

Duarte JLS. Aspectos epidemiológicos da Leishmaniose visceral no Município de Rondonópolis, Mato Grosso, 2003- 2008 [dissertação]. São Paulo: Faculdade de Ciências Médicas da Santa Casa de São Paulo; 2010.

Figueiredo MJFM, Souza NF, Figueiredo HF, Meneses AMC, Filho ES, Nascimento GG. Fatores de risco e classificação clínica associados à soropositividade para leishmaniose visceral canina. Cienc Anim Bras 2014; 15(1): 102-106. http://dx.doi.org/10.5216/ cab.v15i1.25097.

Galgamuwa LS, Dharmaratne SD, Iddawela D. Leishmaniasis in Sri Lanka: spatial distribution and seasonal variations from 2009 to 2016. Parasit Vectors 2018; 11(1): 60. http://dx.doi.org/10.1186/s13071-018-2647-5. PMid:29370864.

Gállego M. Zoonosis emergentes por patógenos parásitos: las leishmaniosis. Rev Sci Tech Off Int Epiz 2004; 23(2): 661-676. http:// dx.doi.org/10.20506/rst.23.2.1512.

Gálvez R, Miró L, Descalzo MA, Nieto J, Dado D, Martin O, et al. Emerging trends in the seroprevalence of canine leishmaniosis in the Madrid region (central Spain). Vet Parasitol 2010; 169(3-4): 327-334. http://dx.doi.org/10.1016/j.vetpar.2009.11.025. PMid:20031330.

Instituto Brasileiro de Geografia e Estatística - IBGE. Censo populacional Nossa Senhora do Livramento 2010 [online]. Brasília: IBGE; 2010 [cited 2019 Mar 10]. Available from: https://cidades.ibge.gov.br/brasil/mt/nossa-senhora-do-livramento/pesquisa/23/25207

Instituto Brasileiro de Geografia e Estatística - IBGE. Panorama da cidade de Nossa Senhora do Livramento em 2018 [online]. Brasília: IBGE; 2018 [cited 2019 Mar 15]. Available from: https://cidades.ibge.gov.br/brasil/mt/nossa-senhora-do-livramento/panorama

Islam A, Rahman MD, Islam S, Debnath P, Alam M, Hassan MM. Sero-prevalence of visceral leishmaniasis (VL) among dogs in VL endemic areas of Mymensingh district, Bangladesh. J Adv Vet Anim Res 2017; 4(3): 241-248. http://dx.doi.org/10.5455/javar.2017. d217.

Lana RS, Michalsky EM, Lopes LO, Lara-Silva FO, Nascimento JL, Pinheiro LC, et al. Ecoepidemiological aspects of visceral leishmaniasis in an endemic area in the Steel Valley in Brazil: an ecological approach with spatial analysis. PLoS One 2018; 13(10): e0206452. http://dx.doi.org/10.1371/journal.pone.0206452. 
Leal GGA, Carneiro M, Pinheiro ADC, Marques LA, Ker HG, Reis AB, et al. Risk profile for Leishmania infection in dogs coming from an area of visceral leishmaniasis reemergence. Prev Vet Med 2018; 150: 1-7. http://dx.doi.org/10.1016/j.prevetmed.2017.11.022. PMid:29406075.

Lima ID, Lima ALM, Mendes-Aguiar CO, Coutinho JFV, Wilson ME, Pearson RD, et al. Changing demographics of visceral leishmaniasis in northeast Brazil: lessons for the future. PLoS Neg/ Trop Dis 2018; 12(3): e0006164. http://dx.doi.org/10.1371/ journal.pntd.0006164. PMid:29509765.

Margonari C, Menezes JA, Rocha MN, Maia KN, Oliveira ME, Fonseca AL, et al. Public knowledge about and detection of canine visceral leishmaniasis in urban Divinópolis, Brazil. J Trop Med 2012; 2012: 429586. http://dx.doi.org/10.1155/2012/429586. PMid:22991521.

Mato Grosso. Secretaria de Estado de Saúde. Data WareHouse [online]. Cuiabá: SES-MT; 2019 [cited 2019 Oct 1]. Available from: http://appweb3.saude.mt.gov.br/dw/pesquisa/detalhe

Menezes JA, Luz TCB, Sousa FF, Verne RN, Lima FP, Margonari C. Peridomiciliary risk factors and knowledge concerning visceral leishmaniasis in the population of Formiga, Minas Gerais, Brazil. Rev Bras Epidemio/ 2016; 19(2): 362-374. http://dx.doi. org/10.1590/1980-5497201600020013. PMid:27532759.

Missawa NA, Lima GBM. Distribuição espacial de Lutzomyia longipalpis (Lutz \& Neiva, 1912) e Lutzomyia cruzi (Mangabeira, 1938) no estado de Mato Grosso. Rev Soc Bras Med Trop 2006; 39(4): 337-340. http://dx.doi.org/10.1590/S0037-86822006000400004. PMid:17119747.

Molina R, Amela C, Nieto J, San-Andrés H, González F, Castillo JA, et al. Infectivity of dogs naturally infected with Leishmania infantum to colonized Phlebotomus perniciosus. Trans R Soc Trop Med Hyg 1994; 88(4): 491-493. http://dx.doi.org/10.1016/00359203(94)90446-4. PMid:7570854.

Oliveira SS, Araújo TM. Avaliação das ações de controle da leishmaniose visceral (calazar) em uma área endêmica do Estado da Bahia, Brasil (1995-2000). Cad Saude Publica 2003; 19(6): 1681-1690. http://dx.doi.org/10.1590/S0102-311X2003000600012. PMid:14999334.

Organização Pan-Americana da Saúde - OPAS. Leishmanioses: informe epidemiológico das Américas. 6. ed. Brasilia: OMS; 2018a.

Organização Pan-Americana da Saúde - OPAS. Relatório de índice composto de leishmaniose visceral por $2^{\circ}$ nível, análise: País: triênio. Brasilia: OMS; 2018b.

Pimentel DS, Ramos RAN, Santana MA, Maia CS, Carvalho GA, Silva HP, et al. Prevalence of zoonotic visceral leishmaniasis in dogs in an endemic area of Brazil. Rev Soc Bras Med Trop 2015; 48(4): 491-493. http://dx.doi.org/10.1590/0037-8682-0224-2014. PMid:26132498.

Queiroz PVS, Monteiro GRG, Macedo VPS, Rocha MA, Batista LMM, Queiroz JW, et al. Canine visceral leishmaniasis in urban and rural areas of Northeast Brazil. Res Vet Sci 2009; 86(2): 267-273. http://dx.doi.org/10.1016/j.rvsc.2008.07.014.

R Core Team. $R$ : a language and environment for statistical computing [online]. Vienna: R Foundation for Statistical Computing; 2018 [cited 2018 Nov 2]. Available from: https://www.R-project.org/

Ready PD. Epidemiology of visceral leishmaniasis. Clin Epidemio/ 2014; 6: 147-154. http://dx.doi.org/10.2147/CLEP.S44267.

Rondon FC, Bevilaqua CML, Franke CR, Barros RS, Oliveira FR, Alcântara AC, et al. Cross-sectional serological study of canine Leishmania infection in Fortaleza, Ceará state, Brazil. Vet Parasitol 2008; 155(1-2): 24-31. http://dx.doi.org/10.1016/j. vetpar.2008.04.014. PMid:18565676.

Silva TAM, Coura-Vital W, Barbosa DS, Oiko CSF, Morais MHF, Tourinho BD, et al. Spatial and temporal trends of visceral leishmaniasis by mesoregion in a southeastern state of Brazil, 2002-2013. PLoS Neg/ Trop Dis 2017; 11(10): e0005950. http:// dx.doi.org/10.1371/journal.pntd.0005950. PMid:28985218.

Solano-Gallego L, Koutinas A, Miró G, Cardoso L, Pennisi MG, Ferrer G, et al. Directions for the diagnosis, clinical staging, treatment and prevention of canine leishmaniosis. Vet Parasitol 2009; 165(1-2): 1-18. http://dx.doi.org/10.1016/j.vetpar.2009.05.022. PMid:19559536.

Ursine RL, Dias JVL, Morais HA, Pires HHR. Human and canine visceral leishmaniasis in an emerging focus in Araçuaí, Minas Gerais: spatial distribution and socio-environmental factors. Mem Inst Oswaldo Cruz 2016; 111(8): 505-511. http://dx.doi. org/10.1590/0074-02760160133.

World Health Organization - WHO. Epidemiological situation [online]. Geneva: WHO; 2019 [cited 2019 Mar 15]. Available from: http://www.who.int/leishmaniasis/burden

Word Organisation for Animal Health - OIE. Leishmaniosis [online]. Paris: OIE; 2020 [cited 2020 Feb 20]. Available from: https:// www.oie.int/fileadmin/Home/eng/Health_standards/tahm/3.01.11_LEISHMANIOSIS.pdf 